\title{
Note on the systematic status of shrews of the Sorex araneus group in NW Anatolia
}

\author{
Miloš MACHOLÁN*, Maria G. FILIPPUCCI, Lenka SLIVKOVÁ \\ and Shimon SIMSON
}

\begin{abstract}
Macholán M., Filippucci M. G., Slivková L. and Simson S. 1999. Note on the systematic status of shrews of the Sorex araneus group in NW Anatolia. Acta Theriologica 44: 101-106.
\end{abstract}

Although it was assumed that the northern parts of Asia Minor were occupied by the Caucasian shrew, Sorex satunini, some recent findings have cast doubts on the specific status of shrew populations in NW Anatolia. Here, a single shrew from Uludag was studied using enzyme electrophoresis. It was compared to $S$. araneus from Europe and $S$. satunini from NE Turkey as well. The results unequivocally classify the animal under study with $S$. satunini and it is suggested that the common shrew, S. araneus, does not occur either in NW Anatolia or in Asia Minor in general.

Institute of Animal Physiology and Genetics, Academy of Sciences of the Czech Republic, Veveři 97, CZ-602 00 Brno, Czech Republic (MM, LS); Department of Biology, Rome University II "Tor Vergata”, Via O. Raimondo, I-00173 Rome, Italy (MGF, SS)

Key words: Sorex, common shrew, Caucasian shrew, electrophoresis, systematics

\section{Introduction}

Shrews of the Sorex araneus group living in Asian Turkey apparently do not seem to create any systematic difficulties at least as concerns the area along the southern coast of the Black Sea. According to most authors (Osborn 1965 in Sokolov and Tembotov 1989, Spitzenberger 1968, Corbet 1978, Şimşek 1986, Pavlinov and Rossolimo 1987, Dogramaci 1989, Hutterer 1993) that area is occupied by the Caucasian shrew, Sorex satunini Ognev, 1922. This species was formerly referred to as Sorex caucasicus Satunin, 1913, but recently its type series has been found to contain (including the holotype) also specimens of $S$. raddei, the name caucasicus thereby being invalidated (Pavlinov and Rossolimo 1987).

However, the distribution of the Caucasian shrew in Turkey appears to be rather scattered (Fig. 1) and the level of genetic and morphological differentiation among species within the $S$. araneus group in general (eg Hausser et al. 1991,

\footnotetext{
*Address of the corresponding author: Laboratory of Genetics and Embryology, Institute of Animal Physiology and Genetics, Academy of Sciences of the Czech Republic, Veveři 97, CZ-602 00 Brno, Czech Republic, e-mail: macholan@ipm.cz
} 
Ruedi 1998) and between $S$. araneus and S. satunini in particular (Macholán 1996, L. Fumagalli, pers. comm.) is rather low. That is why the specific identification based on morphological criteria (as in the papers cited in the introducing paragraph) could be highly problematic. Obviously, there is a need for careful study of putative $S$. satunini from as many of its Turkish localities as possible.

Recently, two findings have cast particular doubts on the specific status of shrew populations in NW Anatolia. First, it was shown that the population from the vicinity of Demirköy (Kirklareli Distr., Istranca Mts., Thrace), ie the type locality of a subspecies of the Caucasian shrew described by Şimşek (1986) as $S$. caucasicus sultanae, belonged in fact to the common shrew (Zima et al. 1994). This population was later described as the "Istranca" chromosome race by Zima et al. (1997). Their results consequently blurred also Şimşek's systematic classification of Anatolian shrew populations with the Thracian subspecies of $S$. satunini. Second, the only individual from Anatolia hitherto studied electrophoretically was found to be genetically very close to $S$. araneus populations from the Balkan Peninsula (M. G. Filippucci and S. Simson in Macholán 1996). Unfortunately, no karyotypic data have been presented in either of the reports on shrews from Anatolia published up to date (Fig. 1).

A recent chromosomal and allozyme survey of Sorex satunini from NE parts of Asia Minor (Macholán 1996) focused on the level and partitioning of genetic

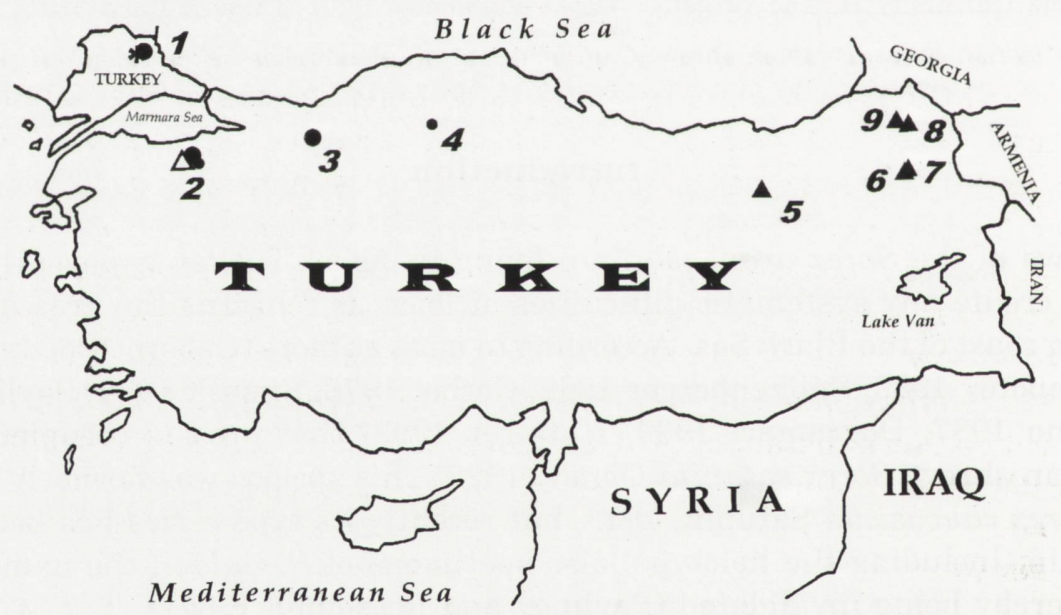

Fig. 1. Map of Turkey with sites indicated from which data on Sorex araneus and $S$. satunini were reported: 1. Demirköy (Kirklareli); 2. Uludag (Bursa); 3. Abant (Bolu); 4. Tosya (Kastamonu); 5. Güzyurdu (Gümüşhane); 6. Handere (Kars); 7. Sirbaşan (Kars); 8. Bagdaşan (Kars); 9. Yalnizçam Geçidi (Artvin). Closed circles: morphological data on shrews described as $S$. caucasicus sultanae (Simşek 1986); dots: morphological data by Spitzenberger (1968) on S. satunini; asterisk: type locality of the "Istranca" chromosome race of S. araneus (Zima et al. 1997); open triangle: the individual investigated in this study; closed triangles: electrophoretic data on S. satunini (Macholán 1996). Note: Güzyurdu was erroneously ascribed to the District of Bayburt by Macholán (1996). 
variation both within and among $S$. satunini populations, and between the Caucasian and common shrew as well. Only a single locus, Est-2, was found to be diagnostic and three other loci (Gpd-2, Mpi, Pgm-3) appeared to be partially diagnostic between the two species (Macholán 1996). This finding urged us to reevaluate the individual studied by Filippucci and Simson since the kidney esterases were then not scored by them.

\section{Material and methods}

A single female of the shrew, supposedly belonging to the Sorex araneus group, was collected at Uludag, Bursa District, $1400 \mathrm{~m}$ a.s.l., on 22 May 1990. The animal was examined with standard horizontal starch gel electrophoresis at 33 presumptive enzymatic loci. Details of the methods and loci scored here are described in Macholán et al. (1994) with the only exception of Pgm-3 which replaced Acph. Tissue homogenates were run on the same gels side by side with samples of both the common and Caucasian shrew.

Special attention was paid to esterase-2 (Est-2; kidney), phosphoglucomutase-3 (Pgm-3; kidney), and mannose phosphate isomerase ( $M p i$; kidney, muscle). Designation of esterases followed nomenclature suggested by Searle (1986). Allele frequencies in a reduced set of 27 loci were then compared with populations of $S$. satunini from NE Turkey and $S$. araneus from the Czech Republic, Slovenia and Macedonia (Macholán 1996) and a UPGMA phenogram was constructed on Nei's genetic distances (Nei 1972). BIOSYS-1 program of Swofford and Selander (1981) was used for all the analyses.

\section{Results}

None of all the scored loci was found to be heterozygous in the animal under study. Particularly, the Uludag shrew was homozygous for alleles $\mathrm{Mpi}^{120}$ and $P g m-3^{85}$, and, more importantly, it was proven to be homozygous for Est-2 ${ }^{90}$, ie one of two alleles unequivocally diagnosing the Caucasian shrew. The zymogram of kidney esterases and its diagrammatic representation illustrates the diagnosis quite clearly (Fig. 2): whereas two faster alleles, $E s t-2^{100}$ and $E s t-2^{105}$, are typical of $S$. araneus, two slower alleles, Est-2 ${ }^{90}$ and $E s t-2^{95}$ (the latter hitherto found only in the heterozygous condition) discriminate $S$. satunini. A UPGMA dendrogram based on Nei's distances (Fig. 3) shows genetic relationships of the studied animal with other $S$. satunini populations and $S$. araneus as well.

\section{Discussion}

According to Macholán (1996), alleles $M p i^{120}$ and $P g m-3^{85}$ are prevailing or even exclusively present in $S$. satunini populations from north-eastern Turkey while they are rare in S. araneus. On the other hand, $M p i^{100}$ and $P g m-3^{100}$, ie the most common alleles for $S$. araneus at the respective loci, have not at all been found in $S$. satunini up to now. This further strengthens the conclusion based on the presence of the diagnostic allele Est-2 ${ }^{90}$ that the Uludag specimen should be 


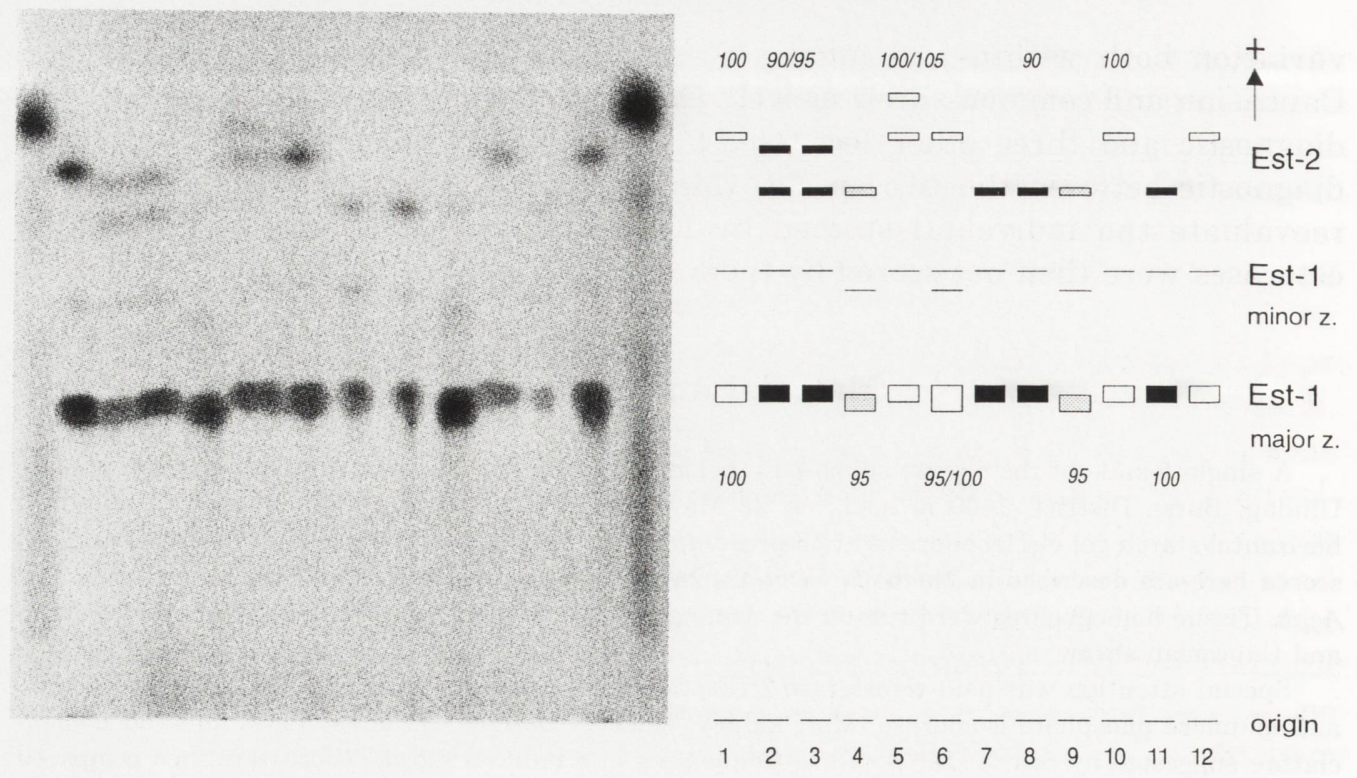

Fig. 2. Zymogram (left) and its diagrammatic representation (right) of the gel stained for kidney esterases using $\alpha$ - and $\beta$-naphthyl propionate as a substrate. From top to bottom: Est-2, Est-1 minor zone and Est-1 major zone (after Searle 1986). Samples 2, 3, 7, 8, 11 are S. satunini from NE Turkey (filled symbols); 1, 5, 6, 10, 12 are $S$. araneus from Kostelec (Czech Republic, open symbols); samples 4 and 9 represent a single individual from Uludag (cross-hatched symbols). References of the C57BL/6 mouse inbred strain are shown on the left and right sides of the zymogram.
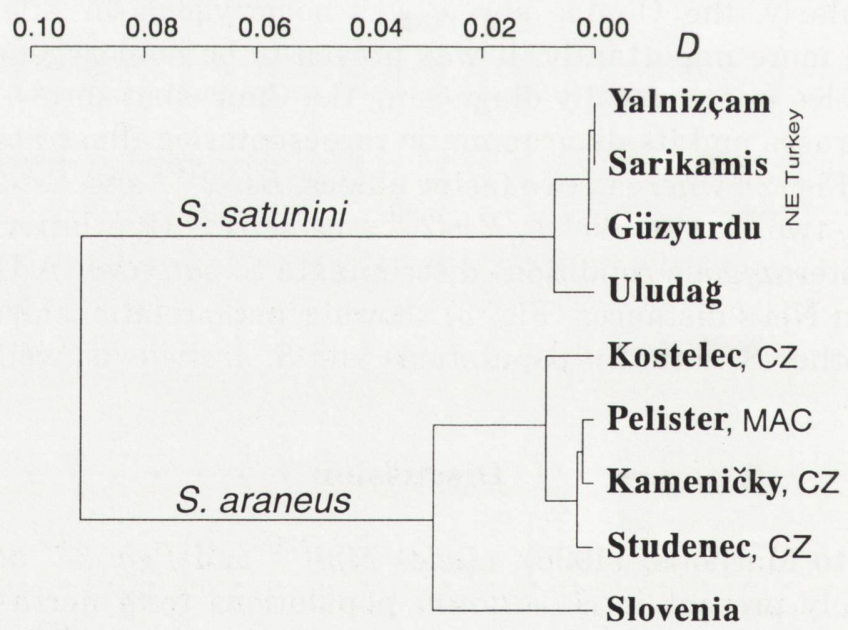

Fig. 3. UPGMA dendrogram based on Nei's genetic distances $(D)$ at 27 loci. Allelic frequencies of both $S$. araneus and $S$. satunini (except Uludag) populations were taken from Macholán (1996). Abbreviations: CZ - Czech Republic, MAC - Macedonia; Yalnizçam denotes pooled localities 8 and 9 whereas Sarikamis denotes localities 6 and 7 in Fig. 1. 
classified with $S$. satunini. This result corroborates morphological data by Spitzenberger (1968) and Şimşek (1986) but, at the same time and in spite of extremely limited material, it is the first and only unequivocal evidence that the westernmost distribution limit of the Caucasian shrew reaches north-western Anatolia (Pavlinov and Rossolimo 1987, Dogramaci 1989, Sokolov and Tembotov 1989, Hutterer 1993).

Obviously, one specimen from a single locality does not allow to reevaluate previous Turkish findings of $S$. satunini as well as to exclude with certainty a possibility of the occurrence of the common shrew in the western parts of Asian Turkey. None the less, according to descriptions by Spitzenberger (1968) and Şimşek (1986), specimens investigated by those authors seem to have been morphologically very similar (especially in coloration) to those from north-eastern Turkey studied by Macholán (1996). Moreover, the Caucasian shrew prefers virtually the same habitats as the common shrew (Sokolov and Tembotov 1989) and thus the two species may be regarded as ecological vicariant counterparts like, for instance, another pair of shrew species, Sorex minutus/S. volnuchini (Zima et al. 1997).

On the other hand, results of karyological studies on a shrew population in the Istranca Mts., carried out by Zima and colleagues (Zima et al. 1994, 1997), suggest that $S$. satunini have not crossed the Bosporus to reach the European continent. Thus far, it can be hypothesized that $S$. araneus does not occur in Asia Minor at all and $S$. satunini is the only representative of the $S$. araneus group there.

Acknowledgements: We are grateful to J. B. Searle, M. Ruedi and two anonymous referees for their useful comments on the manuscript. This work was partly supported by the GA CR grant 204/93/0531 and the GA ASCR grant A6045601/1996 (to M. M.).

\section{References}

Corbet G. B. 1978. The mammals of the Palaearctic region: a taxonomic review. Cornell University Press, London: 1-314.

Dogramaci S. 1989. The mammalian fauna of Turkey. Ondokuz Mayis Üniversitesi Dergisi 1: 107-136. [In Turkish with English summary]

Hausser J., Bosshard F., Taberlet P. and Wójcik J. M. 1991. Relationship between chromosome races and species of the Sorex of the araneus group in the Western Alps. Mémoires de la Société vaudoise des Sciences naturelles 19: 79-95.

Hutterer R. 1993. Order Insectivora. [In: Mammal species of the world. A taxonomic and geographic reference. D. E. Wilson and D. A. M. Reeder, eds]. Smithsonian Institution Press, Washington and London: 69-129.

Macholán M. 1996. Chromosomal and allozyme characterization of the Caucasian shrew, Sorex satunini, from north-eastern Turkey. Hereditas 125: 225-231.

Macholán M., Filippucci M. G., Zima J., Kryštufek B. and Simson S. 1994. Karyological and allozyme survey of the Common shrew, Sorex araneus, from Macedonia. Zeitschrift für zoologische Systematik und Evolution-forschung 32: 129-136.

Nei M. 1972. Genetic distance between populations. The American Naturalist 106: 283-292.

Pavlinov I. Ya. and Rossolimo O. L. 1987. [Systematics of the mammals of the USSR]. Moscow University Press, Moscow: 1-284. [In Russian] 
Ruedi M. 1998. Protein evolution in shrews. [In: Evolution of shrews. J. M. Wójcik and M. Wolsan, eds]. Mammal Research Institute Polish Academy of Sciences, Białowieża: 269-294.

Searle J. B. 1986. A trimeric esterase in the common shrew. Journal of Heredity 77: 121-122.

Simşek N. 1986. A new subspecies of Sorex caucasicus (Mammalia: Insectivora) from Turkey. Turkish Journal of Biology 10: 206-208.

Sokolov V. E. and Tembotov A. K. 1989. [Vertebrates of the Caucasus. Mammals, Insectivores]. Nauka, Moscow: 1-547. [In Russian]

Spitzenberger F. 1968. Zur Verbreitung und Systematik türkischer Soricinae (Insectivora, Mamm.). Annalen des Naturhistorischen Museums Wien 72: 273-289.

Swofford D. L. and Selander R. K. 1981. BIOSYS-1: a FORTRAN program for the comprehensive analysis of electrophoretic data in population genetics and systematics. Journal of Heredity 72 : 281-283.

Zima J., Macholán M., Filippucci M. G., Reiter A., Andreas M., Lípa M. and Kryštufek B. 1994. Karyotypic and biochemical status of certain marginal populations of Sorex araneus. Folia Zoologica 43, Suppl. 1: 43-51.

Zima J., Slivková L., Andreas M., Benda P. and Reiter A. 1997. Karyotypic status of shrews (Sorex) from Thrace, European Turkey. Zeitschrift für Säugetierkunde 62: 315-317.

Received 1 September 1997, accepted 8 September 1998. 